\title{
THE REDUCTION OF LABOR TURNOVER IN THE PLIMPTON PRESS
}

\author{
By Mrs. Jane C. Williams,
}

Employment Manager, Plimpton Press, Norwood, Mass.

The manufacturing of books is the business of The Plimpton Press and this industry is divided into three classes of work: typesetting, printing and binding. About seven years ago, the Taylor system of scientific management was introduced, and at the same time, an employment department was established, whose immediate object was to centralize in one department the hiring, disciplining and discharging. As the new system of management by gradual processes effected economics in the cost of production, so the employment department enlarged its scope and in time became responsible for savings in the human cost of this industry.

One of the early results of the improved methods of handling materials, routing, etc., was to show that the plant was overmanned and the number of people employed was reduced from between 800 and 900 to approximately 500 . This change took place over a period of three years and was not brought about by discharging. When an employe left, he was not replaced by hiring a new worker, but by transferring from within. The working force at the present time numbers about 500,300 of whom are men while 200 are women.

The management of The Plimpton Press, realizing that a large part of the workers' lives is spent within the factory, endeavors to make the surroundings acceptable. The work rooms are high and there is no crowding of workers; in fact, more space is allowed to each person than usually is found in offices or class rooms. This fact of ample room, especially around each machine, accounts in large measure, we believe, for the low percentage of accidents. The work rooms are well supplied with windows and these furnish proper light and ventilation. The entire lighting system, both natural and artificial, has been studied by experts, and work benches and machines are so arranged that no eye strain can result to the workers.

The nature of the work is clean and there is an ample force constantly at work to keep the factory clean. This effort meets with 
much approbation on the part of the people who readily complain at any omission. The lighting, ventilation and cleaning are a part of the responsibility of the factory nurse.

\section{THE WORK OF THE NURSE}

A trained nurse is in charge of the hospital, including an office, a rest room and a surgical room, located in the central part of the factory. Here all accidents and illnesses are cared for. The accidents consist chiefly of minor cuts and bruises, and since these are given proper care at once, the danger from infection is minimized and very little time is lost to the worker because of accident hazards. The book-binding industry, owing to its use of heavy machinery, is not as a whole free from maiming injuries. . The low percentage of such injuries which we have experienced in the last eight years, we believe is due to the following causes: proper lighting, ample work space, guarded machinery, care in selection of operators and freedom from hurry.

In addition to the first-aid service, the nurse performs much preventive and educational work in the plant and social service in the community. The personal contact resulting from the various activities of the service department has made it possible to get in touch with home conditions. The visiting of homes was brought about gradually and at first only by the expressed wish of the individual. Now such visits are welcomed and the nurse visits all who are away from work more than one day.

The results of the work of the nurse cannot be overestimated. She has opportunities for closer relations with workers than has any other person. She hears directly and indirectly of dissatisfactions which would not otherwise be known. When her vision is broad, she brings about a sympathy between the viewpoints of the employer and employe.

\section{Problems Due to Seasonal Demand}

A large part of the work done by The Plimpton Press is the making of school text-books, and the seasonal character of this work is due to the fact that school boards make their adoptions late in the school year. In consequence, the peak of the production curve occurs during July and August and the lowest point during January and February. This in turn affects the workers, as some reduction 
in the force and in the hours of employment is inevitable. Every effort is made by the sales department to counteract this condition by procuring work for the dull season and a measure of success is resulting. Besides this, the following methods have been adopted: every worker is taught several operations so that he may be transferred from one department to another as the work fluctuates; the minimum force is retained as the permanent force; and this force is increased only when absolutely necessary. In this minimum force, there is very little turnover, 81 per cent of the entire number having been in the employ of the The Plimpton Press over five years; 27 per cent, over ten years.

The work hours are from $7: 30$ to $5: 15$, or eight and three quarters hours daily, with one hour allowed for lunch, except on Saturdays, when the hours are 7:30 to 11:45, making forty-eight hours per week. This applies to all workers. There is very little overtime and no Sunday or holiday work.

Rest periods of ten minutes morning and afternoon are given to routine workers, such as monotype keyboarders, gold layers and the accounting force, and during this time the windows in these rooms are open. These periods also furnish an opportunity for the worker to take some exercise.

\section{Source and Nature of the Labor Supply}

The Plimpton Press is located in a community which is able to furnish a large part of the necessary supply of labor. The policy of filling vacancies by promotion within the ranks results in the hiring chiefly of unskilled workers who usually are young. Through friendly relations with the public school officials and teachers, a valuable source of supply for this type of employe is available. Another equally helpful source is found in the present workers who are glad to recommend their friends. In addition, many applicants come of their own accord to apply for work, so that there is a long list of applicants ever available. Under terms of agreement with the trades unions, they have the privilege of supplying workers from among their number, provided they can fill the requirements. If a skilled worker is hired, he usually is obtained in this way.

All candidates for work, except porters, must be English-speaking and have the equivalent of at least a grammar school education. 
Each applicant is interviewed by the employment department and asked to fill out an application blank which is kept on file. On the back of this form are later written the impressions of the interviewer and such other information as may indicate the desirability of the applicant. In this interview, an effort is made to make the applicant feel at ease in order that we may judge of the natural person. It is most desirable to know something of his tastes, his natural aptitudes and his ambitions. One of the chief purposes of the interview is to determine the probable attitude of the worker toward the organization. A person is never hired on the day when he first applies for work, as it is desirable to consider the applicant apart from the first appearance which he makes.

In order to get at just the requirements necessary for each job, work is now being done on "job analyses," which means a careful analysis of each particular job in its relation to each particular worker. This includes, besides the time study of the job, a careful study of the home conditions, temperament and age of the worker, all physical surroundings of the workplace, such as air, accessibility to toilets, rest periods, possibilities of sitting, ventilation, light, noise, any nervous strain resulting from the nature of the work, methods of payment, relations of this job to the rest of the organization, and all other features which may make that job different from any other job. This job analysis should show just the proper requirements for the best kind of worker on that particular job, and enable the employment department to choose that individual who will suffer least from working in that particular position, as well as bring the best results in point of production.

The efforts to steady employment by transferring workers from one department to another as work fluctuates necessitate, in making a selection of a worker, the consideration of two factors: first, the adaptability of the worker to the particular job in question; and second, the adaptability to the two or three other jobs at which the applicant may be called upon to work; that is, given two applicants, one especially well adapted to the particular job for which he is being considered, the other, though not so well adapted for that particular job, better fitted for the group of jobs at which he may be required to work during dull periods, the selection would be made of the second worker. 


\section{Initiating a New Employe}

It is the purpose of the employment department when hiring a new worker to tell him something of the general policies and standards. The candidate is then taken to the factory nurse, who questions him in regard to his health and who explains some of the special features of the service department. If the applicant is a girl, she is introduced to the head of the department in which she is to work. She is also taken to her workplace, introduced to those who will become her fellow-workers, given a key to a locker, and told of such other features as may be desirable for her to know. If the person hired is a boy or a man, he is taken to the head of the department, who in turn takes him to his workplace and follows a similar procedure. The first impression made upon the employe is most important, as at no other time is his mind so open.

The group boss in charge of any group of workers, which in practice does not number more than ten, is responsible for all instruction in regard to the work to be taught to the new employe. There are also written instructions relating to the performance of all tasks. Responsibility for all other training and education rests with the employment department. In this field of activity, the aim is to assist the employe in developing his own abjlities and in discovering latent capacities if they exist, and to make opportunities for their use in this plant if possible. It sometimes happens that this business does not furnish the best avenues for future growth and in these cases, attempts are made by this department to find the right environment for the worker elsewhere.

The employment department keeps in touch with the newly appointed employes by interviewing them at least once a month to see that they are fitted for their work, are given such assistance as they may need, and to find out how they react to the work. A record is kept of each employe from the time of his employment. Information in regard to age, education, marriage, parentage, nationality, number of dependents and previous employment is obtained from the application blank. Dates of increase in pay, transfer, etc., together with reasons for the same, are entered as they occur. On the back of the sheet, spaces are provided for entries, once every thirteen weeks, for:

(a) An estimate of the excellence or the reverse of the discipline which the worker has maintained; 
(b) His efficiency as determined by his bonus earnings in departments where a bonus is paid;

(c) The name of the group boss in consultation with whom the employment manager has formulated his report;

(d) The total number of hours during that period the individual was employed, the hours he was out on his own time, and the bonus hours he made;

(e) His total earnings as shown by the payroll. Space is also provided for items concerning the worker which may affect his work, such as home conditions, etc.

It is with a view to finding out what the average weekly wage per year is for each worker that this record is made, which shall show quarterly the exact amount of money each one has acutally taken home during that period. It does not so much matter to the worker what his rate per hour or per week may be. The important thing to him is the amount he earns over a period of time. A man's hourly rate may be high, but if he has short time, his wages are still small. Unless actual figures covering a definite length of time are periodically brought to the attention of someone whose business it is to safeguard the interests of the employe, many maladjustments of wages escape even a well-intentioned management which believes wages are high because rates are so.

It is the custom to consider each employe once at least in every six months to ascertain whether or not he is deserving of an increase in pay, and if he is, it usually is granted. If he is not deserving of an increase, he is interviewed and the reasons for withholding the raise are talked over with him. This increase in pay continues until the rate equals the union scale.

\section{Discharge and Discipline}

The authority for final discharge rests with the head of the employment department. Group bosses or others in authority may recommend for discharge and, if upon investigation of the case in hand and presentation of proper data on both sides, it seems desirable that the worker be discharged, it devolves upon the employment manager to perform that duty. Individuals may, if they feel that the decision is unfair, take the matter to the works manager, but this privilege has never been used. An employe has the privilege at any time of taking a complaint to the employment department or works manager.

Discipline is reduced to a minimum by the system of manage- 
ment which is self-disciplinary in its operation, but such matters as require discipline are usually attended to by the employment manager. A joint committee to consider all grievances brought before it has worked well. This committee consists of a union representative, usually the president of the local union, a representative from the department where the grievance occurs, the works manager, who represents the firm, and the employment manager, who is a neutral party on the committee. A great variety of subjects are brought before this committee, as for example, such questions as certain piece workers doing a little extra work during the noon hour, rearrangement of locker rooms, distribution of work, and similar matters. Questions of pay which are not concerned with union agreements, but merely affect a special piece of work, are also brought up for discussion at these meetings. So far all grievances have been discussed and settled on a basis of facts and to the mutual satisfaction of all parties concerned. The great benefit resulting from these meetings has been the training of the members to look at the various questions from point of fact rather than from tradition or someone's personal opinion. Once facts are established, there is seldom any argument as to the right action.

\section{Importance of Maintaining Close Contact}

Realizing that any group in society advances only as its individual members advance, the employment department endeavors to know each worker individually, and this is brought about not only by direct methods, but by other avenues which it has at its command for getting into close touch with the employes. An important channel is the library, consisting of several hundred books of nearly every description. Fiction is most sought for, of course, but there is a demand for technical books, travels, music, art, etc. Foreigners are often very glad to be shown what kind of books to read, and it is possible frequently to give them almost a graded course. Many of them read philosophy, history, economics, etc., and are grateful for help in the selection of their books. Others of course need a much simpler line of reading, but follow suggestions readily. Technical and trade magazines are sent monthly to those likely to be interested in the special contents.

As a result of observation of the faulty habits of diet prevailing among those who brought lunches, the project of establishing a lunch 
room was discussed with a number of the employes. The idea met with such hearty coöperation that three years ago a small lunch room was started. Food is served at cost, and, with the exception of the cook, service is voluntary, being given by members of the office force. Practically no one-suffering from indigestion now reports to the hospital in the afternoon.

Recreational activities outside of the factory are not now carried on. Norwood has a civic center of exceptional excellence where gymnasiums, swimming pool, bowling alleys, dance halls, club rooms, sewing and millinery classes, etc., are open to all by the payment of a small fee.

The employes, with the coopperation of the management, have organized two voluntary associations, The Plimpton Savings Bureau and the Plimpton Mutual Benefit Association. The management of both associations is controlled entirely by the employes.

\section{The Operation of the Savings Bureau}

The Savings Bureau was founded with the object of promoting thrift among the employes, 80 per cent of whom are members. Annual deposits total usually about $\$ 15,000$ and the present balance is $\$ 11,000$. A depositor is required to pledge a stipulated weekly amount of from ten cents up, but he may deposit as much more as he chooses any week. Withdrawals may be made at any time. Each department has its own collector and collections are made on the weekly pay day. Interest on deposits is paid at the rate of $4 \frac{1}{2}$ per cent per annum. Many people save money for their insurance, rent, other periodic bills, vacations and Christmas in this way. Depositors may borrow sums not exceeding $\$ 100$ upon furnishing proper security. Where workers have fallen victims to loan sharks, installment buying, etc., it has been possible in many cases, to make arrangements, by means of weekly deposits in the bank, to pay off these debts. At the same time, the man learns something of thrift in saving for future needs.

As an example of the kind of work that has been done through the bank, the following illustration may be of interest. A man who had been in our employ for a number of years and whose work was proving more and more unsatisfactory, finally had three assignments upon his wages come in almost simultaneously. In taking the matter up with him in an effort to make an arrangement so that he could 
obtain releases by paying into our bank a small amount on each one of these assignments weekly, he finally disclosed the condition of his home finances. He was very heavily in debt and was endeavoring to pay on about twenty back bills which covered a term of at least five years. Much of his money had gone foolishly, some of it for liquor and other equally unnecessary expenses, and both he and his wife had reached a hopeless state of mind. We were able to suggest many economies to them and help them make up a budget so that they saved something weekly in the bank for all monthly expenses, such as rent, insurance, and something toward all back bills. In a year's time, he had paid up two-thirds of his indebtedness and his work had improved sufficiently so that he had been given two increases owing to his added value to the business. He is now considered one of the best workers in his department. Although not an habitual drinker, he had been in the habit of celebrating on holidays. The instilled interest in his family affairs and expenses in contrast to his former indifference replaces his need for occasional dissipation.

\section{The Mutual Benefit Association}

The Plimpton Mutual Benefit Association was organized six years ago to provide a sick and death benefit for its members. It is entirely self-supporting. Each member pays fifty cents monthly and may, upon presentation of a doctor's certificate, receive benefits of $\$ 7.50$ per week for thirteen weeks, with a possible additional benefit for thirteen weeks more of $\$ 3.50$ per week. In case of death, the beneficiaries receive $\$ 75$.

All employes are insured under the Workmen's Compensation Act and each case in which compensation is due is carefully followed up by the nurse to see that full benefit is received. Compensation for accident, other than payment of hospital and doctor's bills, does not begin until two weeks from the date of injury. Realizing that many injuries do not require two weeks' absence and that loss of pay for the first two weeks is often the hardest part of the burden of accident, The Plimpton Press pays full wages for these two weeks to its injured employes when such injuries are not caused by wilfulness. The Press also furnishes at the local hospital a free bed which may be used by employes and their families.

An agency for insuring with the Massachusetts Savings Bank 
Life Insurance is maintained. This is a state organization and furnishes insurance at a minimum expense.

\section{Methods of Payment}

Four methods of payment operate in this plant:

(1) Salaries: These are paid to the office and administrative force.

(2) Hourly rate: These are paid to nearly 50 per cent of the entire force.

(3) Task and bonus: Task and bonus is paid to about 43 per cent of the force. This method consists of a flat wage rate which the worker receives in any case. In addition, a worker is given the opportunity to earn an additional amount by performing satisfactorily a certain fixed task.

(4) Piece rate.

Weekly rates of pay for women in the bindery working on an hourly or task and bonus basis are from $\$ 6$ to $\$ 9.12$ plus task bonus, which amounts to from $\$ 1$ to $\$ 2$. Piece workers average about $\$ 15$ for a full week's work. The weekly rates for women in the composition department range from $\$ 6$ to $\$ 22$. In all departments the range is from $\$ 6$ for the younger boys to $\$ 23$ for journeymen, according to the operation each performs.

\section{The Problem of Labor Turnover}

Since 1912, the percentages of the labor turnover have been as follows:
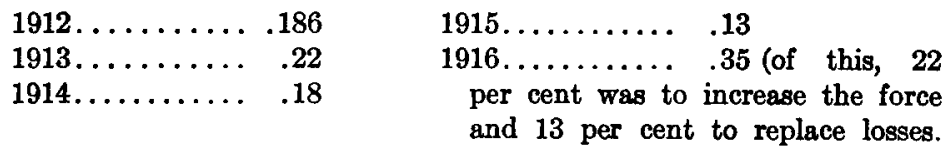

The problems of turnover so far as they affected this establishment had been successfully dealt with until the year 1916. This year presented entirely new problems and efforts to solve them are now being undertaken. A large percentage of the increase in turnover was among the unskilled workers. Among the new aspects the following are most prominent:

(a) The abnormally high rates of wages paid to unskilled labor drew many of this class to the cities and to other plants working on war contracts. We were unable to equal the rates.

(b) The unusual demand for labor made a scarcity of this commodity and as our busy season begins much later than those of other 
industries in our locality, the best workers had been engaged before we went into the market. Consequently we were forced to hire a lower grade of help than in former years and they, in many cases, proved undesirable or unstable. There are two possible solutions to this problem-either to retain a larger working force or to increase our force at an earlier date.

(c) In accordance with agreements with the unions, they are given the first opportunity to furnish skilled workmen. This bperates well when the union headquarters are in the same locality, but when they are in the city, as is the case with the Typographical and Pressmen's Unions, they furnish unstable force. Workers sent out to small towns naturally return to the city as soon as the opportunity presents itself. This problem brings up the question as to the advisability of training an even greater number of our own employes.

Every industry has problems of employment peculiar to itself, depending in a degree upon the nature of the work, but more especially upon the character of the personnel of the organization. Here innumerable variables enter. Policies which are welcomed by certain classes of society would quickly offend other classes, but in any organization success can come only in the measure of the spirit of coöperation. No class of person likes to be ruled and consequently a democratic internal organization proves to be most satisfactory. On the worker's side, the fact of his having a voice in government increases his self-respect and makes him more ready to take a sporting chance on the results. On the side of the management is the possibility of utilizing the vast fund of experience to be found in the ranks of the workers. Both sides gain the added strength of unity. 